\title{
CULTURED MYOMETRIAL CELLS ESTABLISH COMMUNICATING GAP JUNCTIONS
}

R. Loch Caruso*, D.R. Juberg, V. Caldwell and I.A. Corcos Toxicology Program, Department of Environmental and Industrial Health, The University of Michigan School of Public Health, 109 S. Observatory, Ann Arbor, MI 481092029

*To whom correspondence should be addressed

\section{ABSTRACT}

Myometrial cells were isolated and cultured from term rat uterus. The myometrial origin of the cultures was verified by antibody staining of cellular desmin and $\alpha$-smooth muscle actin. The presence of functional gap junctions was indicated by transfer of radiolabeled nucleotide and microinjected Lucifer yellow dye. The cultured cells expressed mRNA recognized by a connexin43 gap junction CDNA probe. To our knowledge, this is the first report that isolated myometrial cells form gap junctions in culture.

Key Words: Gap junctions, intercellular junctions, cell communication, myometrium, uterus, rat.

\section{INTRODUCTION}

Gap junctions consist of cell-to-cell membrane channels that facilitate the direct transfer of small molecules and ions between cells (DeMello, 1987). These junctional channels allow the rapid propagation of electrical signals and may provide the coupling mechanism for coordination of myometrial contractility during parturition (Garfield et al., 1989). Several gap junction proteins have been identified, and there is evidence for tissue specificity of expression (Beyer et al., 1987; Paul, 1986; Risek et al., 1990). In the myometrium, expression of the gap junction protein, connexin43, has been demonstrated (Risek et al., 1990).

Large numbers of gap junctions are present in the myometrium of rats, rabbits, guinea pigs, sheep and humans at parturition, but are scarce or absent in the non-parturient myometrium (Demianczuk et al., 1984; Garfield et al., 1977, 1979, 1982; Garfield and Hayashi, 1981). Correspondingly, rat myometrial expression of connexin43 mRNA is low until the time before labor, 
peaks during labor, and rapidly recedes following delivery (Risek et al., 1990). In vitro, rat myometrial explants spontaneously form gap junctions, as demonstrated by freeze-fracture microscopy (Garfield et al., 1978). However, to our knowledge, the presence of gap junctions in cultures of isolated rat myometrial cells has not been reported. In this study, we present evidence of gap junctional communication in myometrial cell cultures using two functional assays, and show that the cultures express an mRNA recognized by a connexin 43 cDNA probe.

\section{MATERIALS AND METHODS}

Chemicals. Percoll and density marker beads were from Pharmacia (Piscataway, NJ). Defined, iron-supplemented bovine calf serum was from Hyclone Laboratories (Logan, UT) and cell growth medium was from Gibco Laboratories (Grand Island, NY). The dyes, Lucifer yellow $\mathrm{CH}$ lithium salt and propidium iodide, were purchased from Molecular Probes (Eugene, OR). Latex beads (Fluoresbrite carboxylate microspheres, $0.2 \mu \mathrm{m}$ diameter, $2.5 \%$ solids, were from Polysciences (Warrington, $P A) \cdot\left[{ }^{32} \mathrm{P}\right]-$ labeled dCTP and TTP were purchased from ICN Radiochemicals (Irvine, $C A) .\left[{ }^{3} \mathrm{H}\right]$ uridine was purchased from Amersham (Arlington Heights, IL). DNAIII lambda molecular weight size markers and salmon sperm DNA were from Boehringer-Mannheim (Indianapolis, IN). Trichloroacetic acid was from EM Industries (Cherry Hill, NJ). NTB2 photoemulsion, D-19 developer, general purpose fixer, and $x$-omat film were purchased from Eastman Kodak (Rochester, NY). Ultrapure formamide and RNA size markers were from BRL/Life Technologies (Gaithersburg, MD). $\beta$-Mercaptoethanol was from Manufacturing Chemists, Inc. (Cincinnati, $\mathrm{OH}$ ). All other chemicals, including digestive enzymes (Type III trypsin, Type II collagenase and Type I DNase) and antibodies (mouse monoclonal antidesmin, mouse monoclonal anti- - -smooth muscle actin, FITC-conjugated anti-mouse IgG) were purchased from Sigma Chemical Co. (St. Louis, MO).

Cell culture. Myometrial cells were isolated from the uterus of a Sprague-Dawley rat on day 19 of gestation. Whole uterine tissue was minced and placed in $\mathrm{Ca}^{2+}$ - and $\mathrm{Mg}^{2+}$-free Hank's Balanced Salt Solution (HBSS) containing $150 \mu \mathrm{g} / \mathrm{ml}$ Type III trypsin, $150 \mu \mathrm{g} / \mathrm{ml}$ Type II collagenase and $100 \mu \mathrm{g} / \mathrm{ml}$ Type I DNase. The tissue was then refrigerated for $15-18 \mathrm{~h}$ at $4^{\circ} \mathrm{C}$. Following enzymatic digestion, the tissue was filtered through three layers of cheesecloth, washed twice with $\mathrm{Ca}^{2+}-$ and $\mathrm{Mg}^{2+}$ free HBSS and pelleted by centrifugation. The cell pellet was suspended in $38 \%$ Percoll and centrifuged at 
$30,000 \times \mathrm{g}$ for $30 \mathrm{~min}$. The myometrial cell band (density $=1.05-1.10$ ) was identified with density marker beads, collected, and placed in culture flasks containing growth medium (Eagle's salts [Eagle, 1959] with 2X non-essential amino acids, $1.5 \mathrm{X}$ vitamins, $1.5 \mathrm{X}$ essential amino acids except L-glutamine, $1 \mathrm{mM}$ sodium pyruvate, $5.5 \mathrm{mM}$ D-glucose, $14.3 \mathrm{mM} \mathrm{NaCl}$, and $11.9 \mathrm{mM} \mathrm{NaHCO}{ }_{3}, \mathrm{pH}$ 7.4) supplemented with $10 \%$ calf bovine serum. Cell cultures were maintained at $37^{\circ} \mathrm{C}$ in a $5 \% \mathrm{CO}_{2}$ atmosphere, and subcultured by trypsin digestion as needed to avoid confluence.

The WB rat liver epithelial cells were a gift from Dr. James Trosko (Michigan State University), and were used as controls in the Northern blot analysis. The cells were grown in the medium described above, supplemented with $5 \%$ calf bovine serum. The cells were maintained at $37^{\circ} \mathrm{C}$ in a $5 \% \mathrm{CO}_{2}$ atmosphere, and subcultured by trypsin digestion as needed to avoid confluence.

Desmin and $\alpha$-Smooth Muscle Actin Antibody Assays. Antibody reaction was visualized by indirect immunofluorescence. The fibroblastic human embryonic palatal mesenchyme (HEPM) cell line was purchased from American Type culture Collection (Rockville, MD) and included as a negative control. Cells were plated on coverslips in $60-\mathrm{mm}$ dishes and cultured for two days. Following culture, the cells were fixed with acetone at $-20^{\circ} \mathrm{C}$ for $10 \mathrm{~min}$ and air-dried. The coverslips were incubated with $95 \mu \mathrm{l}$ of bovine calf serum for $30 \mathrm{~min}$ at $37^{\circ} \mathrm{C}$ to inhibit nonspecific binding, then gently rinsed with distilled water, overlayed with $95 \mu 1$ of the designated monoclonal antibody (anti-desmin at 1:20 dilution or anti-actin at 1:600 dilution), and incubated for an additional hour at $37^{\circ} \mathrm{C}$. The coverslips were rinsed in phosphate buffered saline (PBS), and $95 \mu 1$ of FITCconjugated anti-mouse IgG antibody were applied to each coverslip (1:96 dilution). The coverslips were incubated at $37^{\circ} \mathrm{C}$ for either $1 \mathrm{~h}$ (desmin assay) or $30 \mathrm{~min}$ (actin assay). Control coverslips were exposed only to the FITC-conjugated anti-IgG antibody. All antibody dilutions were made in PBS. Coverslips were mounted onto slides, cell side down, and viewed by epifluorescence microscopy.

Microinjection. Myometrial cells were grown to subconfluence $(20,000-35,000$ cells/60-mm dish), and microinjected with PBS containing a mixture of $0.05 \%$ (w/v) propidium iodide and $0.5 \%$ (w/v) Lucifer yellow dyes. Propidium iodide is a DNA-binding dye and will not transfer to adjacent cells (Goulet et al., 1988), while Lucifer yellow is small enough to pass through gap junctions (stewart, 1978). The medium on the culture 
dishes was aspirated following injection of the dyes and replaced with fresh medium. Injected cells were visualized with a Nikon Diaphot inverted microscope under epifluorescence conditions using blue excitation (460$490 \mathrm{~nm}$ ) for evidence of Lucifer yellow transfer and red excitation (510-570 nm) to identify propidium iodide in the injected cell. At least five injected cells were scanned per plate for evidence of Lucifer yellow transfer to cells adjacent to the injected cell. Propidium iodide was also injected alone into some cells to verify that this dye did not transfer.

Radiolabeled Nucleotide Transfer. To monitor transfer of radiolabeled nucleotide, unlabeled recipient cells were cocultured with donor cells double-labeled with $\left[{ }^{3} \mathrm{H}\right]$ uridine and fluorescent latex beads (non-transferable marker) (Pitts and Simms, 1977; Mosser and Bols, 1982). Recipient cells $(75,000 /$ dish) were seeded onto glass coverslips in $60-\mathrm{mm}$ tissue culture dishes and incubated for $24 \mathrm{~h}$. Donor cells were incubated for $24 \mathrm{~h}$ in $25-\mathrm{cm}^{2}$ flasks containing $20 \mu \mathrm{l}$ of the latex bead stock. The donor cells were then washed free of unincorporated beads and incubated with $10 \mu \mathrm{Ci}\left[{ }^{3} \mathrm{H}\right]$ uridine in glucose-supplemented $(0.1 \% \mathrm{w} / \mathrm{v})$ PBS at $37^{\circ} \mathrm{C}$ for $3 \mathrm{~h}$. The donor cells were digested with trypsin, washed twice with $\mathrm{Ca}^{++}-$and $\mathrm{Mg}^{++}$- free HBSS, and added to the recipient cultures at a density of 60,000 cells/dish. The donor and recipient cells were cocultured for $6 \mathrm{~h}$ at $37^{\circ} \mathrm{C}$ in a $5 \% \mathrm{CO}_{2} / 95 \% \mathrm{O}_{2}$ atmosphere, then fixed for 30 min with $7 \%(\mathrm{v} / \mathrm{v})$ ice-cold trichloroacetic acid. The glass coverslips were allowed to air dry, and were coated with photoemulsion (50\% Kodak NTB2). The slides were placed in a light-tight box and stored at $4{ }^{\circ} \mathrm{C}$ for 9-12 days. The slides were developed for $4 \mathrm{~min}$ with Kodak D-19 developer, rinsed with distilled water, and fixed with Kodak Acid Fixer. Using a Nikon Diaphot inverted microscope, recipient cells were identified as non-bead-labeled cells in physical contact with beadlabeled donor cells. The slides were scored for evidence of radiolabeled nucleotide transfer by the development of silver grains in the film overlaying recipient cells. At least 50 cell pairs were scored per slide.

RNA Preparation and Northern Blot Analysis. Standard procedures for RNA isolations, transfers and hybridizations were performed as outlined by Sambrook et al. (1989) with the following modifications.

Total RNA was isolated from cultured cells and rat liver tissue (positive control) following homogenization with a $30 \mathrm{ml}$ glass/teflon homogenizer in $15 \mathrm{ml}$ denaturing solution ( $6 \mathrm{M}$ guanidinium $\mathrm{HCl}, 0.3 \mathrm{M}$ NaOAC, $0.1 \%$ $(\mathrm{v} / \mathrm{v})$ sarcosyl, $0.75 \%(\mathrm{v} / \mathrm{v}) \beta$-mercaptoethanol). A chlo- 

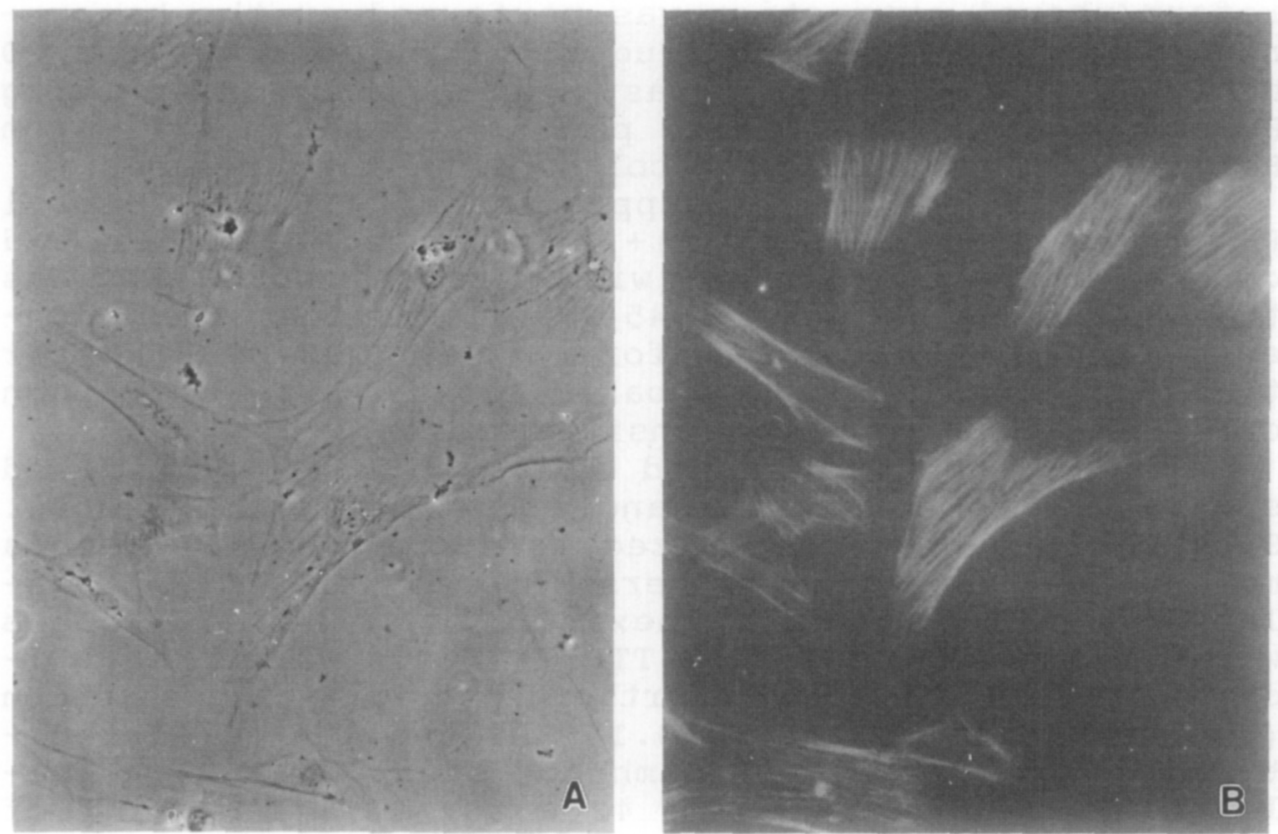

Fig. 1. The myometrial origin of the cells was confirmed by staining with anti-a-smooth muscle actin antibody, visualized by indirect immunofluorescence with an FITC-conjugated second antibody ( $A$, phase contrast; $B$, fluorescence). X141.


Fig. 2. Transfer of Lucifer yellow is indicated by fluorescence in cells adjacent to the microinjected cell (arrow). A, phase contrast; B fluorescence. X225. 
roform/phenol extraction was performed on the homogenate, followed by centrifugation (1300 $\mathrm{x} g)$ for 20 min at $4^{\circ} \mathrm{C}$. Poly $(\bar{A})+$ RNA was prepared from liver using Hybond ${ }^{\mathrm{TM}}$ messenger affinity paper (Amersham, Arlington Heights, IL) with the protocol outlined by the supplier.

For Northern blots, approximately $15 \mu \mathrm{g}$ of total RNA or $5 \mu \mathrm{g}$ liver poly $(A)+$ RNA was electorphoresed on a 0.98 formaldehyde gel with size standards. RNA was transferred to a Nytran ${ }^{\mathrm{TM}} 0.45 \mu \mathrm{M}$ nylon filter (Schleicher \& Schuell, Keene, NA) for $18 \mathrm{~h}$ in $10 \mathrm{X}$ SSPE. After transfer, the filter was baked briefly at $80^{\circ} \mathrm{C}$, then cross-linked using a UV transilluminator.

The filter was halved and each half hybridized separately to connexin32 and connexin43 CDNA probes. Size markers were hybridized to $100 \mathrm{ng}$ DNAIII lambda molecular weight size markers. Probes were nick-translated from $100 \mathrm{ng}$ of connexin 32 or connexin43 cDNAs with [ $\left.{ }^{32} \mathrm{P}\right]-1$ abeled dCTP and TTP. Filters were prehybridized at $65^{\circ} \mathrm{C}$ for $2 \mathrm{~h}$ in Northern hybridization solution (50\% formamide, 5X SSPE, $0.1 \% \mathrm{SDS}$ and $150 \mu \mathrm{g} / \mathrm{ml}$ denatured salmon sperm DNA [Sambrook et al., 1989]), followed by hybridization at $42^{\circ} \mathrm{C}$ for $18 \mathrm{~h}$ in $10 \mathrm{ml}$ of Northern hybridization solution. Filters were washed twice in $5 \mathrm{X}$ SSPE at $65^{\circ} \mathrm{C}$ for $10 \mathrm{~min}$ and once in $2 \mathrm{X}$ SSPE for $10 \mathrm{~min}$, then exposed to Kodak $\mathrm{x}$-omat film.

\section{RESULTS}

Identification of Myometrial cells. The cultured rat myometrial cells bound the anti-desmin and anti- $\alpha-$ smooth muscle actin antibodies, with virtually every examined cell exhibiting fluorescence. The anti-actin antibody clearly stained the actin filaments in the myometrial cells (Fig. 1). The fibroblastic HEPM cells served as a negative control, and accordingly, failed to exhibit antibody staining. Since desmin is predominantly characteristic of muscle cells (Lazarides, 1982), and $\alpha$-smooth muscle actin is an actin isoform specific for smooth muscle cells (Skalli et al., 1986), these results indicate that the cultured uterine cells are of smooth muscle origin.

Transfer of Lucifer Yellow Following Microinjection. Myometrial cells were microinjected simultaneously with propidium iodide and Lucifer yellow, then assessed for transfer of dye to adjacent cells. Propidium iodide was never observed in cells other than the injected cell, verifying its usefulness as a marker of the injected cell. Lucifer yellow was observed in cells adjacent to the injected cell in every case $(n=36)$, denoting the presence of communicating junctions (see example in 


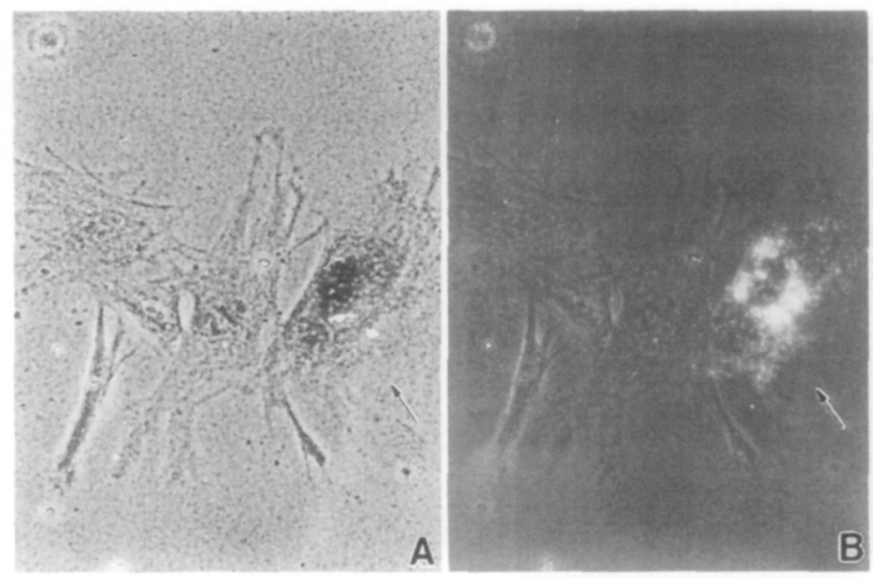

Fig 3. Autoradiograph showing transfer of radiolabeled nucleotide. Donor cells (arrow) are distinguished by the presence of fluorescent latex beads ( $B$, fluorescence) and heavier grain development ( $C$, bright field). Recipient cells are those lacking beads and in contact with donor cells. A, phase contrast. X103.

Fig. 2). Several experiments using cultures of various passages showed similar transfer of Lucifer yellow between myometrial cells (data not shown).

Radiolabeled Nucleotide Transfer. Autoradiographic visualization of radiolabeled nucleotide transfer showed a transfer rate of $86.6 \pm 4.8 \%$ (mean $\pm S D$ of 10 cultures). Donor cells were clearly distinguished from recipients by the presence of fluorescent latex beads and heavier silver grain development (Fig. 3). Those donor-recipient cell pairs in which positive transfer was observed were denoted by the presence of silver grains in the recipient cells, particularly organized around the nucleus (Fig. 3).

Northern Blot Analysis. Total RNA isolated from the cultured myometrial cells hybridized strongly with the connexin43 probe but not with the connexin32 probe (Fig. 4). A single $3.2 \mathrm{~Kb}$ message was recognized by the connexin4 3 probe, similar to the findings of Risek et al. (1990), who reported hybridization with a $3.6 \mathrm{~Kb}$ message in RNA isolated directly from myometrial tissue. RNA from rat liver tissue and cultured WB rat liver epithelial cells served as controls for hybridization to the connexin32 and connexin43 probes, respectively. Total and poly $(A)+$ RNAs from rat liver tissue expressed a 1.6 




\section{$4.4 \mathrm{~Kb} \rightarrow$}

\section{$2.4 \mathrm{~Kb} \rightarrow$}

\section{$1.4 \mathrm{~Kb} \rightarrow$}

Fig. 4. Northern blot analysis of cultured rat myometrial cell and control RNAs with connexin43 (left side, uppercase letters) and connexin32 (right side, lowercase letters) CDNA probes. Lanes $A$ and $a$, rat liver tissue total RNA; $B$ and $b$, rat liver tissue poly $(A)+R N A ; C$ and $C$, WB cell total RNA; and $D$ and d, cultured rat myometrial total RNA. Arrowheads indicate location of 4.4, $2.4,1.4 \mathrm{~Kb}$ RNA size markers. Approximately $15 \mu \mathrm{g}$ total RNA or $5 \mu \mathrm{g}$ poly $(\mathrm{A})+$ RNA were loaded in each lane.

$\mathrm{Kb}$ message that hybridized with connexin32, as reported by Paul (1986), while WB rat liver epithelial cells expressed a $3.2 \mathrm{~Kb}$ message that hybridized with the connexin43 probe (Spray et al., 1990; Trosko et al., 1990) (Fig. 4).

\section{DISCUSSION}

Gap junctions have been identified in rat myometrium using quantitative freeze-fracture microscopy and 2deoxyglucose distribution in myometrial strips (Cole et al., 1985; Cole and Garfield, 1986). However, to our 
knowledge, there are no reports of gap junctions in cultures of isolated rat myometrial cells. Using two functional assays and Northern blot analysis, data from our study suggest that these membrane structures do exist in cultured myometrial cells isolated from pregnant rats.

Indirect immunofluorescence staining with antibodies to desmin and $\alpha$-smooth muscle actin confirmed the myometrial origin of the cultures, since these proteins are characteristic of smooth muscle $(14,15)$. The $\alpha-$ smooth muscle actin antibody better suited our purposes for identifying myometrial cells, as clear staining of the actin fibers was evident.

Microinjection of Lucifer yellow into myometrial cells resulted in transfer of dye to adjacent cells in all cases. Secondary transfer, or transfer from one noninjected recipient cell to another, was common. Propidium iodide was useful as a permanent marker of the injected cell, as this dye did not transfer to adjacent cells.

The radiolabeled nucleotide transfer experiments supported the microinjection studies. Radiolabeled nucleotide transfer was evidenced by silver grain development, heaviest in the donor cells with a lighter pattern in recipient cells. The silver grains were localized around the nuclei in both instances, as a result of RNA incorporation. Gap junction-mediated transfer of radiolabeled nucleotide was less prevalent than transfer of dye following microinjection (87\% vs. 100\%, respectively). Radiolabeled nucleotide transfer may be less sensitive than dye microinjection due to background silver grain development, which increases the difficulty of scoring for transfer and may increase the number of false-negative transfers counted. In addition, different culture conditions may contribute to the variability in intercellular communication levels: established cultures (24-48 h after subculture) were used in the microinjection experiments, while freshly plated cultures $(6 \mathrm{~h})$ were required for the nucleotide transfer experiments.

The gap junction protein expressed in the cultured myometrial cells belongs to the connexin 43 class, based on hybridization of the connexin 43 probe to total RNA isolated from the cells. These results show that the gap junction protein expressed by myometrial cells in culture is similar, and perhaps identical, to that expressed in vivo by the myometrium just prior to and during parturition (Risek et al., 1990).

These experiments have demonstrated the presence of functional gap junctions in cultured rat myometrial cells, and identified an RNA transcript that is recognized by a connexinu 3 cDNA probe. For the study of 
myometrial gap junctions, cell cultures provide several advantages over in vivo models. For example, rapid functional measures, such as those used in the present study, can be easily applied to assess gap junctional responses to hormones, drugs, and toxicants. Furthermore, regulation of the junctions can be probed by manipulation of cell culture conditions. These approaches may facilitate our understanding of the role of gap junctional communication in myometrial function.

\section{ACKNOWLEDGEMENTS}

We thank Dr. Robert Lyons for assistance with the microinjection experiments, $M$. Sue Pahl for assistance with the antibody staining, Dr. stuart Tsubota for assistance with the RNA analysis, Dr. Craig Harris and Dr. Dan Goldman for providing rats, Dr. Jim Trosko for the gift of WB cells and helpful discussions, Dave Hunsche for assistance with photography, and suzan cull for secretarial assistance. This research was supported with grants to R.L.C. (NIH ESO4424 and March of Dimes 15-79)，D.R.J. (predoctoral training grant, NIH ES07062), and R.L.C and I.A.C (University of Michigan Research Partnership Award). Additional support was provided by the Laboratory Animal and Molecular Biology cores of the Reproductive sciences Program (NIH HD18258).

\section{REFERENCES}

Beyer, E.C., Paul, D.L. and Goodenough, D.A. (1987). Connexin43: A protein from rat heart homologous to a gap junction protein from liver. J. Cell Biol. 105, 2621-2629.

Cole, W.C., Garfield, R.E. and Kirkaldy, J.S. (1985). Gap junctions and direct intercellular communication between rat uterine smooth muscle cells. Am. J. Physiol 249, C20-C31.

Cole, W.C. and Garfield, R.E. (1986). Evidence for physiological regulation of myometrial gap junction permeability. Am. J. Physiol 251, C411-C420.

De Mello, w.C. (1987). Modulation of junctional permeability. in: De Mello, W.C. (ed.). Cell-to-Cell Communication. pp. 29-64. New York: Plenum Press.

Demianczuk, N., Towel1, M.E., and Garfield, R.E. (1984). Myometrial electrophysiologic activity and gap 
junctions in the pregnant rabbit. Am. J. Obstet. Gynecol. 149, 485-491.

Eagle, H. (1959). Amino acid metabolism in mammalian cell cultures. Science 130, 432-437.

Garfield, R.E., Sims, S. and Daniel, E.E. (1977). Gap junctions: Their presence and necessity in myometrium

Garfield, R.E., Sims, S.M., Kannan, M.S. and Daniel, E.E. (1978). Possible role of gap junctions in activation of myometrium during parturition. Am. J. Physiol. 235, C168-C179.

Garfield, R.E., Ratrideau, S., Challis, J.R.G. and Daniel, E.E. (1979). Hormonal control of gap junction formation in sheep myometrium during parturition. Biol. Reprod. 21, 999-1007.during parturition. Science 198, 958-960.

Garfield, R.E. and Hayashi, R.H. (1981). Appearance of gap junctions in the myometrium of women during labor. Am. J. Obstet. Gynecol. 140, 254-260.

Garfield, R.E., Daniel, E.E., Dukes, M. and Fitzgerald, J.D. (1982). Changes of gap junctions in myometrium of guinea pig at parturition and abortion. Can. J. Physiol. Pharmacol. 60, 335-341.

Garfield, R.E., Cole, W.C. and Blennerhassett, M.G. (1989). Gap junctions in uterine smooth muscle. in: Sperelakis, N. and Cole, W.C.(eds.). Cell Interactions and Gap Junctions. Vol. II, pp. 239-266. CRC Press: Boca Raton, FL.

Goulet, F., Normand, C. and Morin, O. (1988). Cellular interactions promote tissue-specific function, biomatrix deposition and junctional communication of primary cultured hepatocytes. Hepatology 8, 1010-1018.

Kalimi, G.H., Trosko, J.E., Hampton, L.L., Thorgeirsson, S.S. and Huggett, A.C. (1990). Gap junctional intercellular communication in raf- and ras/myc-transformed rat liver epithelial cell lines. Am. Soc. Cancer Res. Abstract.

Lazarides, E. (1982). Intermediate filaments: A chemically heterogeneous, developmentally regulated class of proteins. Ann. Rev. Biochem. 51, $219-250$.

Mosser, D.D. and Bols, N.C. (1982). The effect of phorbols on metabolic cooperation between human fibro- 
blasts. Carcinogenesis 3, 1207-1212.

Paul, D.L. (1986). Molecular cloning of CDNA for rat liver gap junction protein. J. Cell Biol. 103, 123-134.

Pitts, J.D. and Simms, J.W. (1977). Permeability of junctions between animal cells. Exp. Cell Res. 104, 153-163.

Risek, B., Guthrie, S., Kumar, N. and Gilula, N.B. (1990). Modulation of gap junction transcript and protein expression during pregnancy in the rat. J. Cell Biol. 110, 269-282.

Sambrook, J., Fritsch, E.F. and Maniatis, T. (1989). Molecular cloning, 2nd Ed. Cold spring Harbor Laboratory Press.

Skalli, O., Ropraz, P., Trzeciak, A., Benzonana, G., Gillessen, D. and Gabbiani, G. (1986). A monoclonal antibody against alpha-smooth muscle actin: a new probe for smooth muscle differentiation. J. Cell Biol. 103, 2787-2796.

Spray, D.C., Chanson, M., Moreno, A.P., Dermietzel, R. and Meda, P. (1990). Distinctive types of gap junction channels connect individual pairs of WB cells. Biophys. J. 57, 243 .

stewart, W.W. (1978). Functional connections between cells as revealed by dye-coupling with a highly fluorescent naphthalimide tracer. Cell 14, 741-759.

Trosko, J.E., Chang, C.-C. and Madhukar, B.V. (1990) - In Vitro analysis of modulators of intercellular communication: Implications for biologically based risk assessment models for chemical exposure. Toxicology In Vitro, in press. 